\title{
Positive Effects of Video-based Projects on the Communicative English Grammar Lessons
}

\author{
Nguyen Van My \\ Ho Chi Minh City University of Education, Vietnam \\ nguyenmydhsptphcm@gmail.com \\ https://orcid.org/0000-0002-2976-5133
}

DOI: http://doi.org/ 10.36892/ijlls.v3i3.666

\begin{tabular}{|c|c|}
\hline $\begin{array}{l}\text { Received: } \\
\text { 05/08/2021 }\end{array}$ & $\begin{array}{c}\text { Abstract } \\
\text { The present study investigates positive effects of video-based projects on }\end{array}$ \\
\hline Accepted: & $\begin{array}{l}\text { communicative English grammar lessons in the Vietnamese context. A mixed } \\
\text { method was used in which the responses of forty Vietnamese learners from a } \\
\text { center of English as a foreign language }(E F L) \text { were analyzed. The online } \\
\text { questionnaires and individual interviews were applied for investigating the }\end{array}$ \\
\hline $\begin{array}{l}\text { Keywords: } \\
\text { CLT approach, } \\
\text { communicative } \\
\text { grammar teaching, } \\
\text { Covid-19 era, } \\
\text { smartphone } \\
\text { assistants, video- } \\
\text { based projects }\end{array}$ & $\begin{array}{l}\text { perceptions of the learners in the effectiveness of video-based projects in } \\
\text { communicative grammar lessons. To measure the dependent variables of the } \\
\text { study, the two grammar tests were given to the learners as a pre-test and post- } \\
\text { test. The findings propose that implementing video-based projects in } \\
\text { communicative instructions of English grammar enhances the learners } \\
\text { interests and motivation. Generally, the participants show improvements in } \\
\text { their English grammar performances. In addition, applications of video-based } \\
\text { projects supported the English assessment following the communicative } \\
\text { approach in the EFL context. Hopefully, it might be an effective platform for } \\
\text { the development of the learners' self-directed learning abilities and jointly } \\
\text { prepare learners for the uncertain changes in the post-Covid-19 era as well. }\end{array}$ \\
\hline
\end{tabular}

\section{INTRODUCTION}

It would be difficult to straightforwardly address the question of what methods should be used to teach English grammar effectively. In the globalization context today, however, the main goal of learning is to use English in real-life social situations (Richards, 2006). To successfully meet this expectation in the context of teaching English as a foreign language (EFL), not only do the learners need to gain grammar forms, but also regularly and actively use them in the written and spoken production of English. As suggested by Ellis (2006), the grammar taught should be one that emphasizes not just forms but also the meanings and uses of different grammatical structures. In some real-life classrooms, English grammar lessons are less attractive than other aspects of English learning because these lessons are often taught in isolation from contextual meanings. The gap between the abilities of English inside the classroom and the effective use of English in real-life situations is too large.

Over the past decades, applying communicative language teaching approach (CLT) has been considered an effective solution to deal with the aforementioned problems. To illustrate this, the CLT approach makes English grammar lessons more attractive and provides learners with opportunities to use grammar structures in contextual meanings (Richards, 2006; Larsen-Freeman \& Anderson, 2011; Harmer, 2015). Unfortunately, although teachers use communicative activities in grammar lessons, the success of teaching in EFL contexts depends on the interactions in classrooms - the purposeful use of English from teachers and learners inside and outside classrooms. As commented by Nguyen (2021), the learners only interact with others in classrooms or social life when they have certain purposes or needs. Furthermore, the development of communicative skills can only happen 
on the condition that the learners have motivations and opportunities to express their own identity and to relate with the people around them (Littlewood, 2002). As a result, it is important to effectively create a new 24/7 space to maintain the purposeful use of English, in which learners might actively interact with others, constantly exchange information for learning process, and teachers advantageously implement their instructions.

It is possible to state that the Covid-19 pandemic has dramatically changed most aspects of the world. It is important for learners of English to be trained in the essential skills of the 21st-century, including problem-solving skills, which allows learners to critically think of creative solutions to negative situations of the post-Covid-19 era, as well as global challenges arising from unpredictable natural disasters in the future. To cultivate problemsolving and decision-making abilities, project-based learning ( $\mathrm{PjBL}$ )is a reasonable solution. As defined by Holm (2011), "PjBL is a student-centered instruction that occurs over an extended time period, during which students select, plan, investigate and produce a product, presentation or performance that answers a real-world question or responds to an authentic challenge" (p.1). In terms of language teaching, the implementation of PjBL in English classrooms provides learners with opportunities to transfer what they learn inside classrooms to meaningfully produce language outside through working in small groups and completing projects.

For learners today, the use of smartphones is mostly an integral part of their daily life, thereby the integration of smartphone assistants can be completely conducted in real-life contexts. Based on the apps of video conference functions (e.g., zoom, or video-call on smartphones) and the fast Internet connection, learners can conveniently implement their projects from a different time and place without any direct interaction. The present study was an attempt to highlight how implementing smartphone assistants, especially video functions in project-based learning (or so-called video-based projects) improves the effectiveness of the communicative English grammar lessons in the Vietnamese context. The present study aims to seek possible answers to the following research questions:

Research Question 1 (RQ1): To what extent does implementing video-based projects improve the effectiveness of communicative English grammar lessons?

Research Question 2 (RQ2): What might be done to enhance the effectiveness of implementing video-based projects in communicative English grammar lessons?

\section{LITERATURE REVIEW}

\subsection{The effectiveness of technology applications in English grammar teaching}

With the rapid development of technology, English language teaching is more and more engaged with computers, personal devices, and Internet applications. As suggested by Benson (2011), new technologies are providing the learners in poor language-targeted environments with practical language opportunities beyond classrooms through the internet and social media. Most outstandingly, a smartphone has widely become a very common device, which facilitates great conditions for language learning and teaching through its available functions and applications (e.g., WhatsApp, Zalo, Tik Tok, Facebook, or Twitter). Over the past decades, many previous studies have explored the advantages of using mobileassisted language learning (MALL). In a most recent study, Al-Ahdal and Alharbi (2021) indicate that using MALL as a tool of collaborative learning not only improves the learners' performances on vocabulary but also raises the learners' motivations and engagements in learning. Furthermore, smartphone assistants with the internet connection create a new learning space, in which the learners might conveniently use online available resources for their further practices beyond classroom-learning environments. Therefore, the teachercentered instructions seem to be an extremely limited approach, compared to the advanced features in smartphone apps (Godwin-Jones, 2017). 
In terms of English grammar teaching, AbuSeileek (2009) concludes that computerbased instruction of grammar is effective for learners in learning more complex and elaborate structures (i.e., compound and complex sentences). Similarly, when learning and teaching some grammatical rules (i.e., tenses, conditional sentences, conjunctions, possessive adjectives, and irregular verbs), according to a recent report by Khodabandeh and Soleimani (2018), computer-assisted language learning (CALL)-based tasks have a slight effect on students' grammar learning. For teaching "subject-verb agreement" deductively, Khan et al. (2018) find out that using "Desire2Learn (D2L) Educational software" improves not only learners' learning outcomes but also learner's attitudes towards using D2L software in grammar learning outside the class.

\subsection{The effectiveness of project-based activities in English grammar teaching}

Previous studies on the positive effects of PjBL in language teaching mostly focus on the development of the $21^{\text {st }}$ century skills, including problem-solving skills, critical thinking skills, or interpersonal skills (Richards, 2006; Condliffe, 2017). To prepare learners for the globalization, it is necessary to improve the learners' cultural understanding of Englishspeaking countries. The cultural understanding is also an important aspect of the language acquisition, which enables learners to appropriately and effectively use targeted language (i.e., grammatical structures, or conversational strategies) in real-life situations. Consequently, what teaching methods to raise the learners' cultural awareness is an issue that has been paid attention from many ELT scholars around the world. Of these, Akharraz (2021) suggests that learners, whose culture study through project-based activities, profoundly enhance their cultural awareness of the English cultures at the level of cultural products, cultural practices, and cultural perspectives.

Despite the existence of many different arguments, the engagement among the learners in the class through project-based activities is still examined as an important impact on the self-study development. In term of the grammar teaching, the learners could correct grammar errors together (peer correction) when practising English in groups or pairs. In mixed-level classrooms, the lower-level learners might learn from others. As regards to the English-language learning environment in the EFL context, using project-based activities with applications of technology is considered an effective approach to improve the interactions and engagements between learners, and facilitates ongoing practices of English outside classrooms (Nguyen, 2021). Thanks to the advantages of technology, project-based activities might help the learners maintain the purposeful use of English, interactively exchange information for learning process, and teachers constantly implement their instructions.

\section{METHODOLOGY}

\subsection{Research site and participants}

Participants consisted of forty Vietnamese learners $(n=40)$, whose age ranged from 16 to 23 with the mean age of 19.5 at an EFL center (Ho Chi Minh City, Vietnam). 30 participants (14 males, 16 females) were students at different universities, while the remaining 10 participants (08 males, 02 females) were studying in upper-secondary school. Most of them (28/40) are placed in the pre-intermediate level of English (A2), while some of them (12/40) are determined in the intermediate level of English (B1), corresponding to the Common European Framework Reference for languages (CEFR). All participants have accumulated from three to seven years of experience learning English as the first foreign language (depending on the particular curriculum of each area in Vietnam). More importantly, they were willing to participate in the study and provided their speaking records in the project-based activities, as well as responded to survey questions of this study actively. 
To be more convenient for the trial teaching, all participants were randomly divided into two classes $\left(\mathrm{n}_{1}=\mathrm{n}_{2}=20\right)$.

Prior to collecting data, all participants were given information about the purpose of the study and the anonymous processing of their data. Furthermore, the participants responded to a pre-treatment survey about certain applications of smartphone assistants and the internet. The findings demonstrated that the majority of the participants $(96.2 \%)$ owned at least a smartphone, whereas others used personal devices (e.g., laptops, or tablets) with the available internet connection. They frequently spent more than 04 hours per day for using smartphones or laptops and connecting to the internet. Furthermore, they were guided on how to use some special functions namely text-to-speech programs or movie/TV scripts creations at some websites, or how to use smartphone apps for English learning and how to participate in the online google classroom accounts.

\subsection{Data collection}

In order to collect data, the researcher concurrently used quantitative and qualitative methods, including intervention design, online questionnaires, pre-post-tests, and individual interviews. The convenience sampling technique, which enables the researchers to select suitable participants who are willing to be studied (Creswell, 2012), was used to collect data. Being equivalent to the purpose of this study, this collecting method is suited to exploratory studies which aim to examine theories rather than creating a representative sample (Neuman, 2014). The data collection lasted in 16 weeks, including one week for pre-testing and choosing a population, thirteen weeks for trial teaching, one week for post-testing, the survey and interviews, and one week for video-based project collection and transcript analysis (Figure 1).

Figure 1: The data collecting process

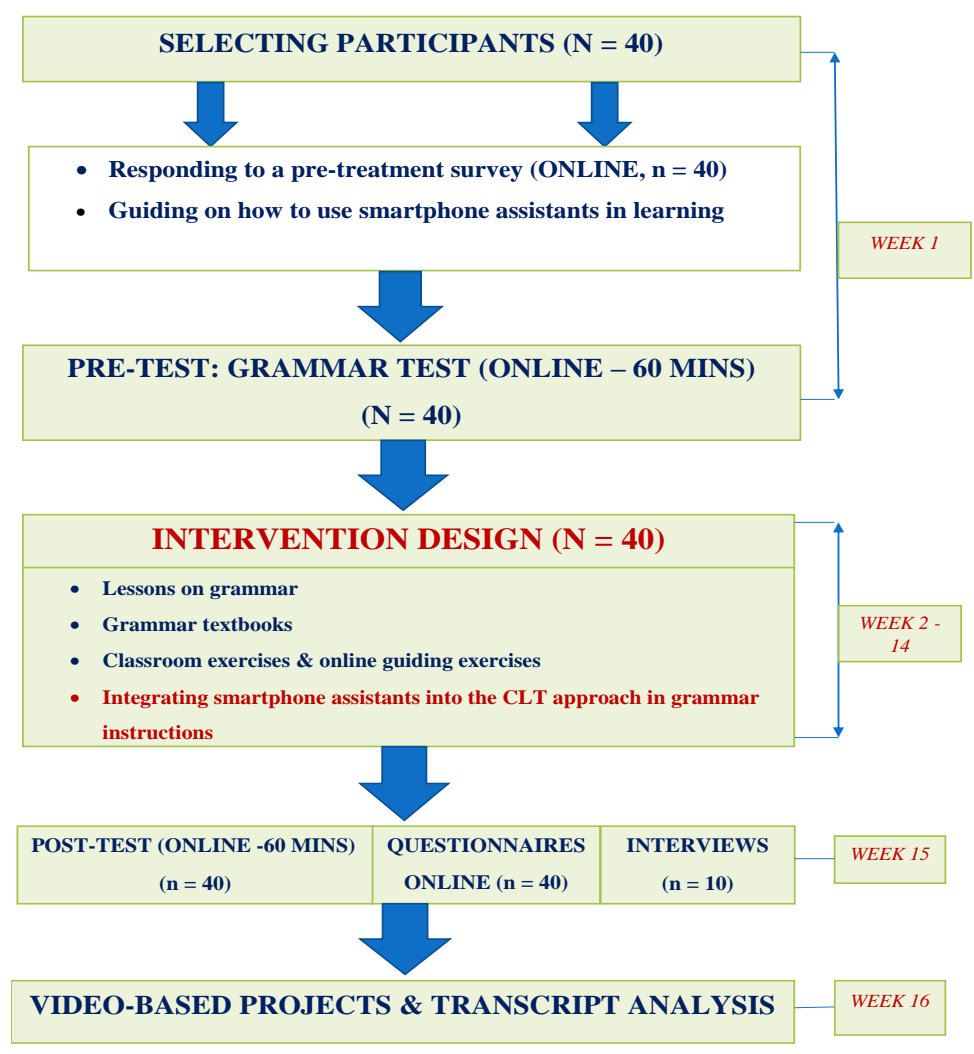

Intervention Design: To adequately address the research questions, the researcher designed a module of an English grammar course in which video-based projects were integrated into the CLT approach to instructing English grammar. The course included twelve lessons 
relating to several targeted English grammar topics: (1) tenses verbs of English; (2) question formulations; (3) sentence structures; (4) reported speech; (5) modal verbs in English. The course was based on several grammar books (e.g., Destination B1 - Grammar and Vocabulary - Mann \& Taylore-Knowes, 2011, or Grammar Practice for Intermediate learners - Walker \& Elsworth, 2000). The purpose of the course was for the learners to reflect on how to use the targeted English grammar structures in both oral and written production. All lessons of the course were instructed by the author in the two individual classes, using the same learning materials and teaching approaches to maximize consistency (Table 1).

Table 1: Schedule of the Grammar Topics

\begin{tabular}{|c|l|}
\hline Week & \multicolumn{1}{|c|}{ Topics } \\
\hline $\mathbf{2}-\mathbf{6}$ & Tenses verbs of English (i.e., present simple, past simple, and simple future) \\
\hline $\mathbf{7}$ & Question formulation (i.e., yes-no questions, and WH-questions) \\
\hline $\mathbf{8 - 9}$ & Sentence structure (i.e., simple sentences, compound sentences, and complex sentences) \\
\hline $\mathbf{1 0 - 1 1}$ & Reported speech \\
\hline $\mathbf{1 2 - 1 4}$ & Modal verbs in English (i.e., modal verbs for expressing possibilities, abilities, obligations, requests) \\
\hline
\end{tabular}

\section{The teaching procedure of the English grammar course}

In communicative grammar lessons, the participants were encouraged to work in groups (from 05 to 07 participants) or pairs. In each lesson, the participants discussed and made presentations about targeted English grammar structures. Moreover, the participants played different roles, dramatized stories, or made short conversations in real-life social situations (making interviews, booking rooms in a hotel, ordering foods in a restaurant, or joining in a TV show) in which the learners applied the targeted grammatical structures. For the data collections, the researcher completely recorded the learners' activities by a smartphone.

To implement video-based projects, the participants in small groups made videos about common topics (video-based projects), in which the learners apply the new grammatical structures learned in their speaking (a video-based project sample - Appendix D). After completing their projects, the participants uploaded their videos on an online classroom-account (Google classroom). To increase the participants' interactions, they are required to examine the videos together, following the video assessment rubric - the learners' version (Appendix C). To require the participants to seriously participate in the projects, the researcher also examined the participants' videos following the video assessment rubric - the teacher's version (Appendix C). All of the collected videos and audios were transcribed to analyze grammar errors (transcripts functions). Afterwards, the researcher identified some common errors or mistakes in grammar. The transcripts were compared and merged to ensure the highest rate of accuracy.

Grammar pre-test and post-test: To measure the dependent variable of the study, the two grammar tests were given to the participants as the pre-test and post-test of the grammar course. To be more specific, the participants were online pretested (using Google form) in order to ensure that they were equivalent in terms of their knowledge of grammar before participating in the grammar course. The content of pre-posttests was selected from the covered materials of the main course book (e.g., Destination B1 - Grammar and Vocabulary - Mann \& Taylore-Knowes, 2011, and Grammar Practice for Intermediate learners - Walker \& Elsworth, 2000). As proposed by Brown (2004), a pre-test should include a sampling material to be covered in the contents of a particular curriculum. It should be noted that the grammar achievement post-test is totally different from the grammar pre-test in the contents. After participating in the grammar course, an online grammar achievement as a post-test was 
designed to examine the participants' grammar achievements. Particularly, these tests were at level B1 (intermediate), corresponding to the Common European Framework of Reference for languages (CEFR), and included 50 multiple-choice targeted grammatical structure items for learners to answer in 60 mins. A total of forty participants completed the pre-posttests as test-takers.

Questionnaire: The participants were required to respond to the questionnaire featuring a five-point Likert scale, ranging from (1) - strongly disagree to (5) - strongly agree. The questionnaires were conducted online (using Google Forms) to investigate (a) Participants' perceptions on using video-based projects in the communicative grammar lessons with three question items, and (b) Participants' perceptions on their English grammar performances with seven question items, (c) further information about the disadvantages of implementing videobased projects and how to deal with the problems in two open-ended questions (Appendix A). Individual interviews: $A$ total of 10 learners from the two classes $\left(n_{1}=n_{2}=5\right)$ were interviewed to "obtain more detailed, specific information than can be gained from the results of statistical tests" (Creswell, 2012), following the list of interview questions (Appendix B). All of the interviews were administered in Vietnamese for the interviewees' preference and the responses were audio-recorded. The interviews were first transcribed in Vietnamese. Concurrently, the transcribed interviews were translated into English by the researcher. The interview session lasted in 150 minutes (15 minutes for each interviewee).

\subsection{Data analysis}

After the data collection process, both the quantitative and qualitative approaches were concurrently used to analyze the data of the present study (Figure 2).

Figure 2: The collected data analysis process

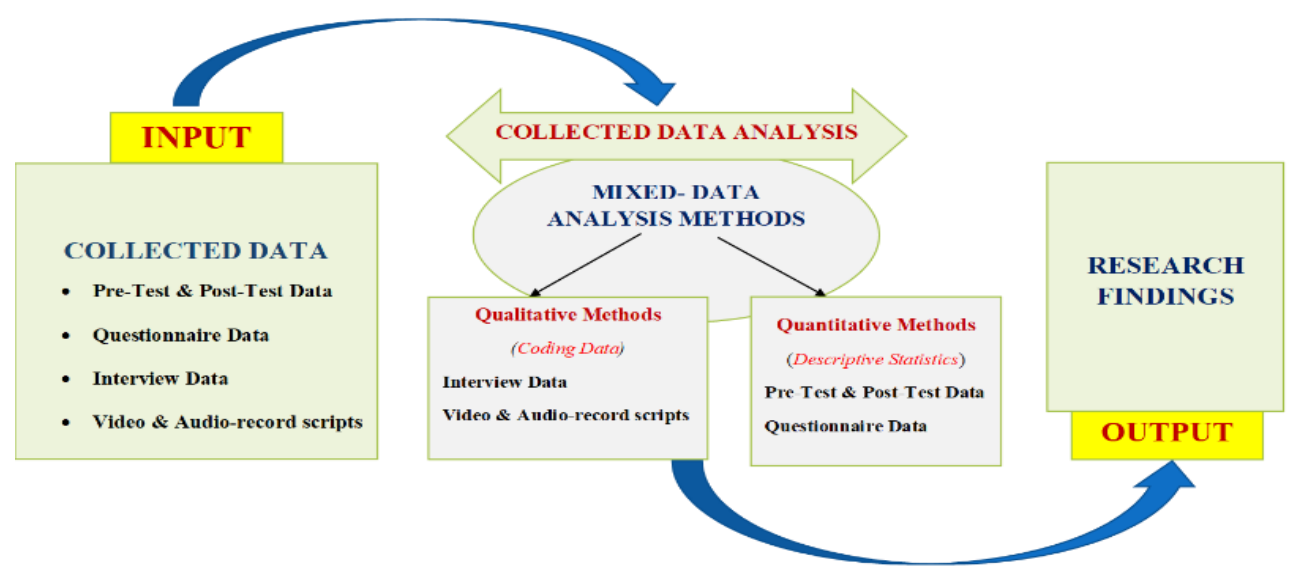

\section{Qualitative Data Analysis}

The qualitative approach (coding data) was also used to interpret the interview data and the learners' further comments from an open-ended question in the questionnaire. According to Creswell (2012), coding data is the process of segmenting and labeling text to form description and broad themes in the data. Particularly, the texts with content as "I am so interested in doing grammar exercises in a small group", "Doing video-based projects makes me more confident in learning English grammar", or "I learned from other learners after working in groups", were coded in the segment "Enhancing the learners' interests and satisfaction in learning". The texts with content as "I could reflect on how to use some English grammar structures in real-life situations", or "I have meaningfully understood some English grammatical points after participating in the English grammar course", were coded in the segment "Improving the learners' performances on English grammar". 


\section{Quantitative Data Analysis}

For marking the learners' scores in the pre-Test and post-Test, a total of fifty corrected answers were 10 points ( 0.2 for each correct answer). It is essential to note that the value of round-off error was approximately between -0.25 and $+0.25\left(\Delta_{R . E r}= \pm 0.25\right)$. To summarize the overall trends or tendencies in collected data (Creswell, 2012), the author used descriptive statistics for quantitative data analysis. To illustrate this, the means and the standard deviations were used to analyze the significant differences between the scores in the pre-Test and those of the post-Test, as well as identify accurately the percentages of participants who responded to the items in the questionnaires on how they agreed or disagreed.

\section{FINDINGS}

\subsection{Enhancing the learners' interests and satisfaction in learning}

The findings from the questionnaire revealed that most of the participants positively viewed video-based projects' interests and satisfaction $(68 \%$ of the participants giving the answer "Agree", and 14\% of the participants giving the answers "Strongly Agree"). In addition, $75 \%$ of the participants believed that these activities increased the interactive practices of English inside and outside classrooms (the percentages of the participants giving the answer "Agree" and "Strongly agree" are 55\% and 20\% respectively). Additionally, the majority of the population suggested that doing video-based projects made grammar lessons more authentic (Figure 3).

Figure 3: The participants' perceptions on using video-based projects in the communicative English lessons

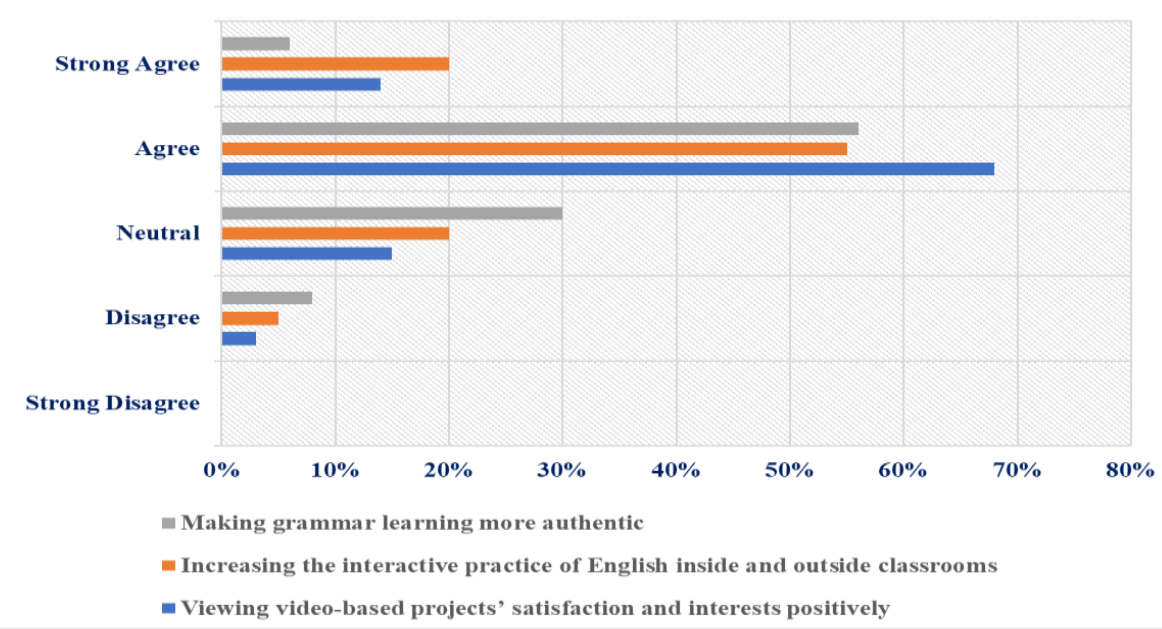

The findings of interviews showed that most of the interviewees $(7 / 10)$ argued that the activities in the grammar course had been very interesting and enabled them to regularly use targeted grammatical points inside and outside classrooms (Extract \# 1).

Extract \# 1: Participants' perceptions on learning activities and doing video-based projects

Interviewee 1: "Well, when doing video-based projects, I was so happy. We worked together to meet the deadline."

Interviewee 2: "Generally, I was very funny after each lesson because I could interact with others to play a role in stories."

Interviewee 3: "Nice! That's all I experienced in this course. Firstly, it has many interesting activities such as role-plays, making interviews, or ordering food in a restaurant". Secondly, I joined the interesting projects outside the class to make funny videos. It's really interesting. 


\subsection{Improving the learners' performances on English grammar}

A total of 12 videos and 60 audio records were collected. Overall, the findings from the analysis of the audio and video transcripts revealed that most of the participants were able to use meaningfully the targeted grammar structures in communicative situations illustrated in the course. Nevertheless, some of the participants made some common errors or mistakes in grammar (e.g., subject and verb agreement, tenses of English verbs, pronouns used in the reported speech, or forms of irregular verbs).

In response to the questionnaires, the majority of participants agreed that they could reflect on how to use effectively the targeted English grammatical points after completing the course. More specifically, 65\% of the participants (26/40) agreed that they were able to use the present simple tense to talk about daily activities, and $20 \%$ of them (8/40) strongly agreed with similar ideas. In terms of using grammar in the real-life situations (e.g., booking a room in a hotel, or shopping in malls), approximately $50 \%$ of the participants agreed that they could use modal verbs in English for expressing possibilities, abilities, or obligations, and over $32 \%$ of them strongly agreed with these ideas (Table 2 ).

Table 2: Perceptions of participants on the effectiveness of video-based projects in communicative English grammar lessons $(n=40)$

\begin{tabular}{|c|l|l|l|l|l|l|}
\hline \multicolumn{2}{|c|}{ After completing the course, I was able to...... } & SD & $\mathbf{D}$ & $\mathbf{N}$ & $\mathbf{A}$ \\
$\mathbf{( 1 )}$ & $\mathbf{( 2 )}$ & $\mathbf{( 3 )}$ & $\mathbf{( 4 )}$ & $\mathbf{( 5 )}$ \\
\hline $\begin{array}{c}\text { Item } \\
\mathbf{4}\end{array}$ & $\begin{array}{l}\text { Use the present simple to talk about daily activities or other } \\
\text { related common topics }\end{array}$ & $0 \%$ & $5 \%$ & $10 \%$ & $\mathbf{6 5 \%}$ & $\mathbf{2 0 \%}$ \\
\hline $\begin{array}{c}\text { Item } \\
\mathbf{5}\end{array}$ & $\begin{array}{l}\text { Use the past simple to talk about the past events or other related } \\
\text { common topics }\end{array}$ & $10 \%$ & $5 \%$ & $30 \%$ & $\mathbf{4 5 \%}$ & $\mathbf{2 0 \%}$ \\
\hline $\begin{array}{c}\text { Item } \\
\mathbf{6}\end{array}$ & $\begin{array}{l}\text { Make correctly question formulations in the communicative } \\
\text { situations }\end{array}$ & $10 \%$ & $2 \%$ & $38 \%$ & $\mathbf{4 0 \%}$ & $\mathbf{1 0 \%}$ \\
\hline $\begin{array}{c}\text { Item } \\
\mathbf{7}\end{array}$ & $\begin{array}{l}\text { Produce accurately sentence structures in the communicative } \\
\text { situations }\end{array}$ & $3 \%$ & $12 \%$ & $35 \%$ & $\mathbf{4 5 \%}$ & $\mathbf{5 \%}$ \\
\hline $\begin{array}{c}\text { Item } \\
\mathbf{8}\end{array}$ & $\begin{array}{l}\text { Use modal verbs in English to express possibilities, abilities, } \\
\text { obligations }\end{array}$ & $11 \%$ & $4 \%$ & $5 \%$ & $\mathbf{4 8 \%}$ & $\mathbf{3 2 \%}$ \\
\hline $\begin{array}{c}\text { Item } \\
\mathbf{9}\end{array}$ & $\begin{array}{l}\text { Use modal verbs in English to express requests in the daily } \\
\text { situations }\end{array}$ & $15 \%$ & $6 \%$ & $14 \%$ & $\mathbf{3 6 \%}$ & $\mathbf{2 9 \%}$ \\
\hline $\begin{array}{c}\text { Item } \\
\mathbf{1 0}\end{array}$ & $\begin{array}{l}\text { Foster innovation and creativity skills, technology skills, } \\
\text { interpersonal skills, problem-based and collaborative learning, } \\
\text { lifelong and student's self-directed learning. }\end{array}$ & $2 \%$ & $8 \%$ & $20 \%$ & $\mathbf{4 0 \%}$ & $\mathbf{3 0 \%}$ \\
\hline
\end{tabular}

Regarding the interview findings, two out of the interviewees also commented that they could use appropriately the targeted grammatical structures in the real-life social contexts. Most of them (6/10) strongly proposed that their understanding of English grammar improved after participating in the course (Extract \# 2).

Extract \# 2: Perceptions of the participants on the effectiveness of video-based projects in communicative English grammar lessons

Interviewee 1: "Well, I think that one of the most useful things I learned from the course is that I could use some special functions to make videos more attractive. Alternatively, I gained how to use some English grammatical structures in the real-life situations, including modal verbs in English for expressing requests in the daily situations, or reported speech."

Interviewee 2: "Certainly, my understanding of English grammar slightly improved after participating in the course. For instance, I frequently made mistakes in some types of 
questions, even confused in the use of English verb tenses. Also, I could confidently speak English without awareness of grammar errors. Thanks to the help from my teammates, I knew the ways to self-correct mistakes in grammar."

Apart from the aforementioned arguments, the researcher found no statistically significant differences in learners' grammar performances between pre-Test and post-Test (Table 3 ).

Table 3: The value distribution of Pre-Test and Post-Test $(n=40)$

\begin{tabular}{ccccc}
\hline & Minimum & Maximum & Mean & St-Deviation \\
\hline Pre-Test & 2.5 & 9.0 & 7.0 & 7.5 \\
\hline Post-Test & 1.5 & 9.5 & 7.5 & 7.5 \\
\hline
\end{tabular}

4.3. Solutions to the problems when implementing video-based projects in communicative English grammar lessons

As can be seen in the findings of interviews, some of the interviewees (4/10) suggested that they coped with difficulties in working in small groups. Particularly, they felt unconfident to communicate with others or present their own ideas while doing video projects. As a matter of fact, the conflicts among the participants frequently happened during completing video projects. In terms of peer corrections, some of the interviewees $(3 / 10)$ admitted that they were sometimes unfair in video evaluations, which sometimes caused conflicts among the groups.

In terms of the participants' perceptions on possible solutions to their problems in doing video-based projects, most of them (7/10) suggested that they preferred to work with those who have in common or similar backgrounds of language proficiency. According to the findings of the questionnaire, the participants frequently commented that they felt more comfortable when working with the same-age members or schoolmates. To effectively work in groups, some of the participants indicated that they first made an agreement about what each member need to do and when they must complete their tasks. Most of them also thought that team leaders should be good enough to support other members and had good administration skills.

\section{DISCUSSIONS}

The answer to the RQ1 follows to what extent video-based projects improve the effectiveness of communicative grammar lessons. From the findings of this study, participants generally had positive opinions of video-based projects' satisfaction and interests. To explain this, doing video-based projects in groups makes the learners more confident in the use of English grammar (approximately $80 \%$ of the population agreed or strongly agreed with similar ideas in the present study). Based on the smartphone assistants, doing video-based projects increased the interactive practices of English inside and outside the class. As a matter of fact, the participants can be more interactive and collaborative with others while doing video-based projects, and confidently practice English without fear of being wrong or of being corrected in front of the class as well. In other words, implementing video-based projects in communicative English grammar lessons seemed to extend learning spaces beyond classroom-learning environments.

In spite of the existence of inevitable errors, the participants could use meaningfully and appropriately English grammar in real-life social situations. As the findings showed, most of the participants strongly agreed that they had opportunities to transfer the grammatical structures learned to real-life communicative situations through participating in learning activities and doing video-based projects outside the class. After completing the grammar course, however, there were no remarkable distinctions of participants' 
performances between the post-Test and pre-Test. To reasonably explain this, there is a mismatch between learning outcomes and assessment methods in the present study. In other words, the main purpose of these tests is to examine the understanding of grammatical structures from the learners, whereas the communicative grammar lessons focus primarily on the use of grammatical structures in real-life situations.

The RQ2 discusses possible solutions to the problems while implementing videobased projects in English communicative grammar lessons. Despite many positive effects on communicative grammar lessons, implementing video-based projects contains some drawbacks related to individual differences and difficulties in group work. To ensure the effectiveness of project-based activities, it is suggested that the learner's interactions and collaboration are prerequisites. Actually, the learners' interactions depend on similar backgrounds of the characteristics or genders. In addition, the learners' collaboration is influenced by backgrounds of knowledge and language proficiency, especially in group discussions. This might explain why some of the participants felt more comfortable when working with the same-age members or schoolmates. Additionally, some difficulties in doing video-based projects result from the fact that learners have poor experiences in group work or communication skills. Indeed, the findings indicated that there were conflicts among the participants and groups, even some participants felt unconfident to communicate with others or present their own ideas when implementing video-based projects.

To effectively deal with these problems, it is necessary for the teachers to have detailed instructions before requiring the learners to do video-based projects. These instructions should include how to successfully work in small groups and what each member needs to complete. In this case, the teachers play an important role in both preparing learners for group work and administering what learners are doing. More importantly, the teachers should personalize the assessment process while implementing project-based activities in teaching. This means that the teachers considerably examine each individual's abilities and tasks in group work and ensure that the product assessments are fair to all groups.

Going back to the EFL context, using video-based projects in communicative English grammar lessons seems to be a model for internalizations of similar projects in various local situations. Hopefully, it contributes to successful applications of the CLT approach and holistic changes in assessment methodologies in the future. For illustrative purposes, when learners complete video-based projects, the teachers indirectly assess not only the student's performances on English grammar or attitudes in learning but also improvements of learners' essential skills (e.g., innovation and creativity skills, technology skills, interpersonal skills, solving problem skills, and personal responsibility). In other words, it is necessary to transfer from traditional tests such as multiple-choice tests to the performance-based assessment which "measure learner learning based on how well the learner can perform on a practical real-world task such as the ability to write an essay or carry out a short conversation" (Richards \& Schmidt, 2010, p.428).

\section{CONCLUSION}

The present study investigates the effectiveness of video-based projects in communicative grammar lessons in the Vietnamese context. The participants showed improvements in their English grammar performances at the end of the study. In terms of perceptions of their experience, participants viewed video-based projects interesting and motivating. From these findings, teachers should apply the CLT activities inside classrooms to encourage the learners to practice English grammar meaningfully and interactively. Concurrently, it is important to use group-work appropriately, especially project-based activities to maximize the interaction and engagement between learners outside classrooms. Teachers also need to integrate the advantages of technology into teaching to provide the learners with more opportunities to practice the targeted grammar structures in real-life 
situations. It might also be an effective platform for the development of the learners' selfdirected learning abilities. In a review of the literature on project-based learning, Condliffe (2017) proposes that project-based learning often enables learners to collaboratively or independently work on learner-directed activities for extended periods of time. In addition, it could fulfill the gaps between the abilities of English inside classrooms and real-life situations and jointly prepare learners for uncertain changes in the post-Covid-19 era as well.

On the other hand, some inevitable limitations might have influenced the results obtained. Due to the differences in linguistic characteristics between English and Vietnamese (mother language - L1) and the learners' understanding of English grammar, it was difficult to consistently use communicative activities for all targeted grammatical structures (L2) in the present study. In other words, some targeted English grammar structures that are similar to the Vietnamese ones, applying communicative activities is effective. Meanwhile, others are extremely different from the Vietnamese structures, communicative grammar lessons may more difficult for the learners to elaborate. As mentioned previously, all participants have accumulated from three to seven years of experience studying English as the first foreign language (depending on the particular curriculum of each area in Vietnam). Therefore, the complexity of experiences of learning a language, as well as a diversity of learning strategies from the learners might influence the learners' responses to the questionnaires or interviews.

Future studies could compare and contrast that will draw on the similaritiesdifferences between English and L1, which enables the teachers to appropriately apply these results into English grammar lessons. In addition, further studies approaching the individualization to maximize the effectiveness of group-work activities or project-based learning should be conducted in the future. Concurrently, it is neccessary to continue carrying out research on language learning strategy "based on the evolving learner, teacher needs and educational settings etc. by differing research methods and seeking for ways to minimize the challenges of definitional fuzziness and maximize in-depth analysis of the strategic behaviors of the learners" (Kölemen, 2021, p. 166).

\section{REFERENCES}

AbuSeileek, A. (2009). The effect of using an online-based course on the learning of grammar inductively and deductively. ReCALL, 21(3), 319-336.

Akharraz, M. (2021). The Impact of Project-Based Learning on Students' Cultural Awareness. International Journal of Language and Literary Studies, 3(2), 54-80. https://doi.org/10.36892/ijlls.v3i2.601.

Al-Ahdal, A. A. M. H., \& Alharbi, M. A. (2021). MALL in Collaborative Learning as a Vocabulary-Enhancing Tool for EFL Learners: A Study Across Two Universities in Saudi Arabia. SAGE Open, 11(1), 1-9. https://doi.org/10.1177/2158244021999062.

Benson, P. (2011). What's new in autonomy? The Language Teacher, 35(4), 15-18.

Brown, H., D. (2004). Language assessment principles and classroom practices. San Francisco, US: Person Education.

Condliffe, B. (2017). Project-based learning: A literature review. Working Paper. MDRC.

Creswell, J. W. (2012). Educational research: planning, conducting, quantitative and qualitative research ( $4^{\text {th }}$ Ed.). Boston: Pearson. 
Ellis, R. (2006). Current issues in the teaching of grammar: An SLA perspective. TESOL Quarterly, 40(1), 83-107.

Godwin-Jones, R. (2017). Smartphones and language learning. Language Learning \& Technology, 21(2), 3-17. Retrieved from http://lit.msu.edu/issues/june2017/emerging.pdf.

Harmer, J. (2015). The Practice of English Language Teaching (5 ${ }^{\text {th }}$ Ed.). Harlow, UK: Pearson Education Limited.

Holm, M. (2011). Project-based instruction: A review of the literature on effectiveness in prekindergarten through 12th grade classrooms. Insight: Rivier Academic Journal, $7(2), 1-13$.

Kölemen, Ülkü. (2021). A Systematic Review of Studies on Language Learning Strategies from 1977 to 2018. International Journal of Language and Literary Studies, 3(1), 151-169. https://doi.org/10.36892/ijlls.v3i1.485.

Khan, M. S., Ali. F., Mustafa, G., \& Farooqi, S. (2018). Effectiveness of anEducational Software System (Desire2Learn) in Teaching English Grammar [Special Issue]. Arab World English Journal (AWEJ) (4), 144-159. Retrieved from https://dx.doi.org/10.24093/awej/call4.11.

Khodabandeh, F., \& Soleimani, H. (2018). The effect of CALL-based tasks on EFL learners' grammar learning. Teaching English with Technology, 18(3), 54-68.

Larsen-Freeman, D., \&Anderson, M. (2011). Techniques and principle in language teaching ( $3^{\text {rd }}$ Ed.). Oxford, UK: Oxford University Press.

Littlewood, W. (2002). Communicative Language Teaching: An introduction (22 ${ }^{\text {nd }}$ Ed.). Cambridge, UK: Cambridge University Press.

Neuman, W. L. (2014). Social research methods: Qualitative and Quantitative Approaches ( $7^{\text {th }}$ Ed.). Boston: Pearson.

Nguyen, V. M. (2021). English language-learning environments in COVID-19 era: EFL contexts, English-language environments, technology-based approach, English language learning. AsiaCALL Online Journal, 12(3), 39-46. Retrieved from https://asiacall.info/acoj/index.php/journal/article/view/21.

Richards, J. C. (2006). Communicative Language Teaching Today. New York, USA: Cambridge University Press.

Richards, J. C., \& Schmidt, R. (2010). Longman dictionary of language teaching and applied linguistics $\left(4^{\text {th }}\right.$ Ed.). Harlow, UK: Pearson Education Limited. 


\section{APPENDICES}

\section{Appendix A \\ QUESTIONNAIRE}

Please answers the following questions by ticking $(\checkmark)$ the corresponding number using the following five-point scale:

\begin{tabular}{|l|l|l|l|l|}
\hline 1 & 2 & 3 & 4 & 5 \\
\hline Strongly Disagree & Disagree & Neutral & Agree & Strongly Agree \\
\hline
\end{tabular}

PART A: Participants' perceptions on using video-based projects in the communicative grammar lessons: I am interested in this course because

1 Doing video-based projects makes me motivated and engaged and in the $\begin{array}{lllll}1 & \mathbf{2} & \mathbf{3} & \mathbf{4} & \mathbf{5}\end{array}$ learning process inside and outside classrooms

$\begin{array}{lllllll}\mathbf{2} & \text { Doing video-based projects makes grammar lessons more authentic } & \mathbf{1} & \mathbf{2} & \mathbf{3} & \mathbf{4} & \mathbf{5} \\ \mathbf{3} & \text { It contains many interesting activities inside and outside the class that enable } & \mathbf{1} & \mathbf{2} & \mathbf{3} & \mathbf{4} & \mathbf{5}\end{array}$ me to practice interactively English with other in pairs or groups inside and outside class

PART B: Participants' perceptions on their English grammar performances: After completing the course, I was able to........

$4 \begin{array}{lllllll}4 & \text { Use the present simple to talk about daily activities or other related common } & \mathbf{1} & \mathbf{2} & \mathbf{3} & \mathbf{4} & \mathbf{5}\end{array}$ topics

$5 \quad$ Use the past simple to talk about the past events or other related common $\begin{array}{lllll}\mathbf{1} & \mathbf{2} & \mathbf{3} & \mathbf{4} & \mathbf{5}\end{array}$ topics

6 Make correctly question formulations in the communicative situations $\quad \begin{array}{lllll}\mathbf{1} & \mathbf{2} & \mathbf{3} & \mathbf{4} & \mathbf{5}\end{array}$

$\mathbf{7}$ Produce accurately sentence structures in the communicative situations $\quad \begin{array}{lllll}\mathbf{1} & \mathbf{2} & \mathbf{3} & \mathbf{4} & \mathbf{5}\end{array}$

8 Use modal verbs in English to express possibilities, and abilities, obligations $\begin{array}{lllll}\mathbf{1} & \mathbf{2} & \mathbf{3} & \mathbf{4} & \mathbf{5}\end{array}$

9 Use modal verbs in English to express obligations, and requests in the daily $\begin{array}{lllll}1 & \mathbf{2} & \mathbf{3} & \mathbf{4} & \mathbf{5}\end{array}$ situations

10 Improve innovation and creativity skills, technology skills, interpersonal skills, $\begin{array}{lllll}\mathbf{1} & \mathbf{2} & \mathbf{3} & \mathbf{4} & \mathbf{5}\end{array}$ problem-based and collaborative learning, lifelong and student's self-directed learning.

PART C: Additional comments: What are the disadvantages of implementing video-based projects? What did you deal with these problems?

\section{Appendix B \\ INTERVIEW QUESTIONS}

1. What personal devices do you have?

2. Is the internet available in your place?

3. How much time do you use your smartphone (or other personal devices) every day?

4. How much time did you use your smartphone to learn English grammar in this English grammar course?

5. Could you tell me about your experience when participating in this English grammar course?

6. What did you like or dislike about this English grammar course? Give a further explanation.

7. How did your grammar performance improve after this grammar course?

8. What challenges did you face when participating in the English grammar course? Give a further explanation.

9. What are the difficulties you are facing when doing video-based projects?

\section{Appendix C}

VIDEO ASSESSMENT RUBRIC - STUDENTS' VERSION

Topic:

Group's name:

Examiner's name:

Leader's name: 
Instructions: Evaluate each criterion below by ticking $(\mathfrak{V})$ the corresponding number using the following four-point scale:

\begin{tabular}{|l|l|l|l|l|}
\hline EVALUATED CATEGORIES & $\begin{array}{l}\text { Needs } \\
\text { improvement } \\
\text { (1) }\end{array}$ & $\begin{array}{l}\text { Fair } \\
\text { (2) }\end{array}$ & $\begin{array}{l}\text { Good } \\
\text { (3) }\end{array}$ & Excellent \\
\hline $\begin{array}{l}\text { Maintaining fewest errors or mistakes in grammar and } \\
\text { pronunciation }\end{array}$ & & & \\
\hline Using enough the required grammar rules & & & & \\
\hline Using enough the required lexical resources & & & & \\
\hline Having a coherent speaking & & & \\
\hline Having the most interesting contents & & & \\
\hline $\begin{array}{l}\text { Having the most effective special functions namely } \\
\text { text-to-speech programs creations or movie/TV scripts } \\
\text { creations }\end{array}$ & & & \\
\hline Overall effectiveness & & & \\
\hline
\end{tabular}

Additional comments:

VIDEO ASSESSMENT RUBRIC - TEACHERS' VERSION

Examiner's name: Group's name: Leader's name:

Instructions: Evaluate each criterion below by ticking $(\mathfrak{V})$ the corresponding number using the following four-point scale:

\section{EVALUATED CATEGORIES}

Maintaining fewest errors or mistakes in grammar and pronunciation

Using enough the required grammar rules

Using enough the required lexical resources

Having a coherent speaking

Having the most interesting contents

Having the most effective special functions namely text-to-speech programs creations or movie/TV scripts creations

All of the group members participated in the video

Being the earliest group uploading the video

Overall effectiveness

Additional comments:

\section{Appendix D}

\section{A VIDEO-BASED PROJECT SAMPLE}

The requirement: Make a video survey about what your friends do every day. Then, make a report about it.

Learning objectives: The purpose of the project is for learners to use the grammatical structures, including the present simple, the past simple, and the reported speech in the real-life situations. In addition, the learners will be able to improve their English skills, focusing on Speaking skills.

\section{Project descriptions:}

1. Making a video survey:

In groups of five or seven, the learners make a video survey in the length of $10-15$ minutes about what their friends do every day. The learners firstly collect information from their friends and record interviews. 


\section{Positive effects of video-based projects on the communicative grammar lessons}

Suggested questions:

- What do you often do in the morning?

- What do you often do in the afternoon?

- What do you often do in the afternoon?

- How do you often spend your day?

Technology equipment: Mobile phones, social networks, and apps for teaching and learning English

2. Making a report:

The learners write a report or make a presentation about their surveys.

Useful language:

According to the survey/As can be found in the survey..., there are/is........ student(s) who (go swim) in the morning. He/she said....

The learners need to use the reported speech in their reports.

Report forms:

\begin{tabular}{|c|c|c|c|c|c|c|}
\hline E禿 & Name & Class & $\begin{array}{l}\text { What to do in the } \\
\text { morning }\end{array}$ & $\begin{array}{c}\text { What to do in the } \\
\text { afternoon }\end{array}$ & $\begin{array}{c}\text { What to do in } \\
\text { the evening }\end{array}$ & Notes \\
\hline 1. & Mai & & & & & \\
\hline 2. & $\ldots$ & & & & & \\
\hline 3. & $\ldots$ & & & & & \\
\hline$\ldots$ & $\ldots$ & & & & & \\
\hline
\end{tabular}

\section{AUTHOR'S BIO}

Nguyen Van My is a researcher in language acquisition and linguistic studies. His current research interests include the language teaching methodology, curriculum developments, technology in language teaching, learner motivations, applied linguistics (Compare-contrast linguistics - Vietnamese - English - Russian), and English-language learning environments. His research interests are reflected in his publications in the areas of English language teaching and technology and the applied linguistics (Compare-Contrast linguistics). 